\title{
Humic substances stimulate maize nitrogen assimilation and amino acid metabolism at physiological and molecular level
}

\author{
Silvia Vaccaro ${ }^{1}$, Andrea Ertani ${ }^{1 *}$, Antonio Nebbioso ${ }^{2}$, Adele Muscolo $^{3}$, Silvia Quaggiotti ${ }^{1}$, Alessandro Piccolo ${ }^{2}$ \\ and Serenella Nardi ${ }^{1}$
}

\begin{abstract}
Background: The effects of a humic substance (HS) extracted from a volcanic soil on the nitrate assimilation pathway of Zea mays seedlings were thoroughly examined using physiological and molecular approaches. Plant growth, the amount of soluble proteins and amino acids, as well as the activities of the enzymes involved in nitrogen metabolism and Krebs cycle, were evaluated in response to different $\mathrm{HS}$ concentrations $\left(0,1\right.$ and $\left.5 \mathrm{mg} \mathrm{CL}^{-1}\right)$ supplied to maize seedlings for $48 \mathrm{~h}$. To better understand the HS action, the transcript accumulation of selected genes encoding enzymes involved in nitrogen assimilation and Krebs cycle was additionally evaluated in seedlings grown for 2 weeks under nitrogen ( $\mathrm{N}$ ) sufficient condition and $\mathrm{N}$ deprivation.
\end{abstract}

Results: $\mathrm{HS}$ at low concentration $\left(1 \mathrm{mg} \mathrm{C} \mathrm{L}^{-1}\right.$ ) positively influenced nitrate metabolism by increasing the content of soluble protein and amino acids synthesis. Furthermore, the activity and transcription of enzymes functioning in $\mathrm{N}$ assimilation and Krebs were significantly stimulated.

Conclusions: HS treatment influenced the gene expression of Zea mays plants at transcriptional level and this regulation was closely dependent on the availability of nitrate in the growth medium.

Keywords: Humic substances; Biological activity; Gene expression; Nitrogen metabolism

\section{Background}

Humic substances (HS) are the major components of soil organic matter (SOM) and positively affect crop production [1] by playing pivotal roles on both soil-plant system [2] and plant metabolism and development [3-6]. The growing concern for sustainable agriculture, whose goals are to ensure lower environmental costs and long-term productivity of agro-ecosystems [7], highlights the importance of developing management strategies to maintain and 1 protect soil resources and, in particular, SOM [8]. Despite this present awareness, the second half of the past century has seen a massive and indiscriminate use of high-energy input in agriculture and in particular of $\mathrm{N}$

\footnotetext{
* Correspondence: andrea.ertani@unipd.it

'Department of Agronomy, Food, Natural Resources, Animal and

Environment, University of Padua, Agripolis - Viale dell'Università, 16, Legnaro, Padua 35020, Italy

Full list of author information is available at the end of the article
}

fertilizers during the so-called green revolution. These practices led to the selection of genotypes, which were highly productive when fed with high nitrogen inputs, though not efficient in nitrogen use [9], while they concomitantly caused a progressive impoverishment of soil physical and biological properties, as well as of SOM and nutrients' bioavailability.

Because of the importance of HS in soil fertility, a larger number of works focused on both the chemical-physical structure and the biological properties of humic matter. HS have been traditionally described as polydispersed heterogeneous organic compounds with large molecular weight [10]. However, recent experimental findings reached a new understanding of the humic conformational nature that is regarded as a supramolecular association of heterogeneous molecules with relatively low molecular weight $(\leq 1.5 \mathrm{kD})$ held together in only apparently large molecular sizes by weak interactions, such as hydrogen and hydrophobic bondings. The metastable conformations of humic 
associations can be reversibly disrupted by interactions with small amounts of organic acids [11,12], while the same amount of acids do not alter conformation of the true macropolymers stabilized by covalent bonds [13]. The supramolecular nature of humic matter and its response to organic acids have been advocated to explain the bioactivity of humus on plants [6], its molecular dynamics [14] and the slow release of sorbed contaminants [15]. Furthermore, the recognition that NOM is composed by supramolecular associations rather than macropolymers has allowed the development of a fractionation strategy, called humeomics, that enables the analytical detection of most of the single molecules which constitute the supramolecular assembly [16-18]. These findings had profound implications on our understanding of SOM function and reactivity.

Several studies have reported the positive effect of HS on crop yield [19-21] and on root and shoot development $[6,22]$. In addition, leaf chlorophyll content [1], nutrient uptake [3,23-26] and the activities of enzymes involved in several physiological pathways, such as nitrogen assimilation [3,24,25,27] and energy metabolism [28-30], seem to be positively affected by HS. However, because of the complexity of HS' nature, the relationship between their molecular structure and biological activity is not yet completely clear. In the last decades, several studies correlated biological activity to humic chemical features [31-41]. The positive effects of different HS in relation to their chemical structure were shown by Muscolo et al. [35] and Nardi et al. [36] on Pinus nigra callus metabolism and Zea mays seedling growth. Moreover, Zancani et al. [42,43] successfully related humic matter molecular features to metabolism of tobacco BY-2 suspension cell cultures and to changes of cellular ATP and glucose-6-phosphate during embryogenesis of Abies cephalonica.

Furthermore, the complexity of the biological action exerted by $\mathrm{HS}$ on plant metabolism suggested the existence of hormonal mechanisms, in particular of an auxin-like effect $[3,4]$. The presence of low amount of IAA in different soil humic substances has been reported $[33,44]$. Moreover, these substances seem to have a physiological effect on both a maize isoform of $\mathrm{H}^{+}$ATPase Mha2 $[34,37,38]$, which is a specific auxin target, and a pea phospholipase $A_{2}$ [45], which is a component of an auxin-dependent signalling.

The objective of this work was to investigate the effect of humic matter on maize nitrate assimilation and amino acids metabolism when the humic concentration was varied. The response of growth, protein and free amino acid content of maize seedlings to humic supply was evaluated here. Moreover, the activity of the main enzymes involved in the Krebs cycle and nitrogen metabolism was determined, together with the expression of genes encoding the enzymes involved in these two metabolic pathways.

\section{Methods}

Soil humic matter extraction and chemical characterization A humic acid (HA) from a Fulvudand soil of the volcanic caldera of Vico, near Rome, Italy, was isolated by standard methods as reported elsewhere [46]. The HA was titrated to $\mathrm{pH} 7.2$ with a $0.5 \mathrm{M} \mathrm{KOH}$ solution in an automatic titrator (VIT 90 video titrator, Radiometer, Copenhagen, Denmark) under $\mathrm{N}_{2}$ atmosphere and stirring. After reaching the constant $\mathrm{pH} 7.2$, the solution containing potassium humate was left under titration for $2 \mathrm{~h}$, filtered through a glass microfibre filter (Whatman GF/C; GE Healthcare, Buckinghamshire, UK) and freezedried. The elemental analyses and the molecular characterization of this HA by online thermochemolysis-GC-MS and CPMAS-NMR spectroscopy were reported earlier [36].

\section{Plant material, growth solutions and HS treatment}

Maize seeds (Z. mays L. var. DK 585) were soaked in distilled water for one night in running water and germinated for $60 \mathrm{~h}$ in the dark at $25^{\circ} \mathrm{C}$ on a filter paper wet with $1 \mathrm{mM} \mathrm{CaSO}_{4}$ [47]. Then, the maize seedlings were raised in hydroponic conditions for 14 days in growth chamber with $450 \mathrm{~mL}$ of a complete nutrient solution $(\mu \mathrm{M})$ containing $\mathrm{KH}_{2} \mathrm{PO}_{4}(40), \mathrm{Ca}\left(\mathrm{NO}_{3}\right)_{2}(200), \mathrm{KNO}_{3}$ (200), $\mathrm{MgSO}_{4}$ (200), FeNaEDTA (10), $\mathrm{H}_{3} \mathrm{BO}_{3}$ (4.6), $\mathrm{CuCl}_{2} \cdot 2 \mathrm{H}_{2} \mathrm{O}$ (0.036), $\mathrm{MnCl}_{2} \cdot 4 \mathrm{H}_{2} \mathrm{O}$ (0.9), $\mathrm{ZnCl}_{2}$ (0.09) and $\mathrm{NaMoO}_{4} \cdot 2 \mathrm{H}_{2} \mathrm{O}(0.01)$. The solution was renewed every $48 \mathrm{~h}$. Growth chamber conditions were the following: day/night period of $14 / 10 \mathrm{~h}$, air temperature of $27^{\circ} \mathrm{C} / 21^{\circ} \mathrm{C}$, relative humidity of $6 \% 0 / 80 \%$ and photon flux density (PFD) of $280 \mu \mathrm{mol} \mathrm{m} \mathrm{m}^{-2} \mathrm{~s}^{-1}$.

To evaluate morphometric parameters, protein and free amino acids content and enzyme activities, on the 12th day of growth, the plants were treated for $48 \mathrm{~h}$ with aqueous solutions in which the freeze-dried potassium humate was dissolved at different concentrations expressed as carbon weight per litre: 0 (control), 1 and $5 \mathrm{mg} \mathrm{C} \mathrm{L}{ }^{-1}$.

To evaluate the transcript accumulation, the HS were applied on the 13 th day at $1 \mathrm{mg} \mathrm{C} \mathrm{L}^{-1}$ for $24 \mathrm{~h}$ to two different control solutions: a complete nutrient solution (see above) and a nutrient solution $\mathrm{N}$-deprived, where $\mathrm{N}$ sources $\mathrm{KNO}_{3}$ and $\mathrm{Ca}\left(\mathrm{NO}_{3}\right)_{2} 4 \mathrm{H}_{2} \mathrm{O}$ were replaced with $\mathrm{KCl}$ and $\mathrm{CaCl}_{2} 2 \mathrm{H}_{2} \mathrm{O}$ at the same concentrations. The expression analyses were performed by semi-quantitative reverse transcriptase-polymerase chain reaction (RT-PCR) on cDNA obtained from leaves and root tissues.

\section{Determination of protein content}

For the extraction of soluble protein, frozen foliar and root tissue $(0.5 \mathrm{~g})$ were ground in liquid nitrogen, stirred with the extraction buffer $(100 \mathrm{mM}$ Tris- $\mathrm{HCl} \mathrm{pH} 7.5$, $1 \mathrm{mM} \mathrm{Na} \mathrm{NaDTA}_{2} 5 \mathrm{mM} \mathrm{DTT}$ ) and centrifuged at $14,000 \mathrm{~g}$. The supernatants were mixed with $10 \%(w / v)$ trichloroacetic acid (TCA) and centrifuged. The pellets 
obtained were then re-suspended in $0.1 \mathrm{~N} \mathrm{NaOH}$. The amount of total proteins in the leaves was determined by using the Bradford method [48] with bovine serum albumin as a standard. The results were expressed as $\mathrm{mg}$ protein/gramme fresh tissue.

\section{Enzyme extraction and assay conditions}

The enzymes were solubilized from leaves by manually crashing vegetal tissues in a mortar added with a $100 \mathrm{mM}$ Hepes- $\mathrm{NaOH}$ solution at $\mathrm{pH} 7.5$, a $5 \mathrm{mM} \mathrm{MgCl}$ solution, and a $1 \mathrm{mM}$ dithiothreitol (DTT) solution. The ratio of plant material to mixture solution was 1:3 w/v. The extract was filtered through two layers of muslin and clarified by centrifugation at 20,000 g for $15 \mathrm{~min}$. The supernatant was used for enzymatic analysis. All steps were carefully performed at $4^{\circ} \mathrm{C}$, while a Jasco V-530 UV-vis spectrophotometer (Jasco Co., Midrand, Gauteng, South Africa) was used for measuring enzyme activity.

The nitrate reductase (NR EC 1.7.1.1) activity was assayed according to Lewis and collaborators [49] and expressed as unit per milligramme protein. One unit corresponds to the production of $1 \mu \mathrm{mol}$ of $\mathrm{NO}_{2}^{-}$per minute at $25^{\circ} \mathrm{C}$.

The nitrite reductase (NiR EC 1.7.1.4) activity was determined on the basis of the drop in $\mathrm{NO}_{2}^{-}$concentration in the reaction medium [50]. After incubation at $30^{\circ} \mathrm{C}$ for $30 \mathrm{~min}$, the $\mathrm{NO}_{2}^{-}$content was determined colorimetrically at $\mathrm{A}_{540}$ and the activity was expressed as unit per milligramme protein. One unit corresponds to the consumption of $1 \mu \mathrm{mol}$ of $\mathrm{NO}_{2}^{-}$per minute at $25^{\circ} \mathrm{C}$.

To evaluate the glutamine synthetase (GS EC 6.3.1.2) activity, the mixture for the assay contained $90 \mathrm{mM}$ imidazole- $\mathrm{HCl}(\mathrm{pH} 7.0), 60 \mathrm{mM}$ hydroxylamine (neutralized), $20 \mathrm{mM} \mathrm{Na} \mathrm{KAsO}_{4}, 3 \mathrm{mM} \mathrm{MnCl}_{2}, 0.4 \mathrm{mM}$ ADP, $120 \mathrm{mM}$ glutamine and the appropriate amount of enzyme extract. The assay was performed in a final volume of $750 \mu \mathrm{L}$. The enzymatic reaction was developed for $15 \mathrm{~min}$ at $37^{\circ} \mathrm{C}$. $\gamma$-Glutamyl hydroxamate (gh) was colorimetrically determined by addition of $250 \mu \mathrm{L}$ of a mixture $(1: 1: 1)$ of $10 \%(w / v) \mathrm{FeCl}_{3} \cdot 6 \mathrm{H}_{2} \mathrm{O}$ in $0.2 \mathrm{M}$ $\mathrm{HCl}, 24 \%(w / v)$ trichloroacetic acid and $50 \%(w / v) \mathrm{HCl}$. The optical density was recorded at $\mathrm{A}_{540}$ [51]. The activity was expressed as unit per milligramme protein. One unit corresponds to the production of $1 \mu \mathrm{mol} \mathrm{mg}$ protein per minute at $37^{\circ} \mathrm{C}$.

$\mathrm{NADH}$-dependent glutamate synthase (NADH-GOGAT EC 1.4.1.14) assay contained $25 \mathrm{mM}$ Hepes- $\mathrm{NaOH}$ (pH 7.5), $2 \mathrm{mM} \mathrm{L}^{-1}$ glutamine, $1 \mathrm{mM} \alpha$-ketoglutaric acid, $0.1 \mathrm{mM} \beta$-NADH, $1 \mathrm{mM} \mathrm{Na} \mathrm{Na}_{2}$ EDTA and $100 \mu \mathrm{L}$ of enzyme extract in a final volume of $1.1 \mathrm{~mL}$. GOGAT was assayed spectrophotometrically by monitoring $\beta-\mathrm{NADH}$ oxidation at $\mathrm{A}_{340}$. The activity was expressed as unit per milligramme protein. One unit corresponds to the oxidation of $1 \mu \mathrm{mol}$ of $\beta$-NADH per minute at $37^{\circ} \mathrm{C}$.
The activity of aspartate aminotransferase (AspAT EC 2.6.1.1) was measured spectrophotometrically by monitoring $\beta$-NADH oxidation at $\mathrm{A}_{340}$ at $30^{\circ} \mathrm{C}$. The assay medium (final volume $2.4 \mathrm{~mL}$ ) contained $100 \mathrm{mM}$ Tris- $\mathrm{HCl}$ at pH 7.8, $240 \mathrm{mM}$ L-aspartate (Asp), $0.11 \mathrm{mM}$ pyridoxal phosphate, $0.16 \mathrm{mM} \mathrm{NADH}, 0.93 \mathrm{kU}$ malate dehydrogenase $(\mathrm{MDH}), 0.42 \mathrm{kU}$ lactate dehydrogenase (LDH), $12 \mathrm{mM}$ 2-oxoglutarate and $200 \mu \mathrm{L}$ enzyme extract [52]. The activity was expressed as unit per milligramme protein. One unit corresponds to the oxidation of $1 \mu \mathrm{mol}$ of $\beta$-NADH per minute at $37^{\circ} \mathrm{C}$.

The activity of asparagine synthetase (AS EC 6.3.5.4) was determined by incubating $10 \mathrm{mM}$ glutamine (Gln), $30 \mathrm{mM}$ ATP, $10 \mathrm{mM}$ Asp, $10 \mathrm{mM} \mathrm{MgCl} 2,2 \mathrm{mM}$ DTT, $0.1 \mathrm{mM}$ EDTA, Hepes $50 \mathrm{mM}$ pH 7.75 with $400 \mu \mathrm{L}$ of the desalted extract in a total volume of $500 \mu \mathrm{L}$ at $30^{\circ} \mathrm{C}$ for $60 \mathrm{~min}$. The reaction was terminated with $100 \mu \mathrm{L}$ of sulfosalicylic acid $\left(200 \mathrm{mg} \mathrm{mL}^{-1}\right)$, centrifuged and an aliquot of the supernatant, adjusted to $\mathrm{pH} 7.0$ with $\mathrm{NaOH}$ and taken for the analysis and separation of Asp and Asn by HPLC of the ortho-phthalaldehyde (OPA) reagent derivates [53]. The activity was expressed as unit per milligramme protein. One unit corresponds to the production of $1 \mu \mathrm{mol}$ of Asn per minute at $30^{\circ} \mathrm{C}$.

For the assay of citrate synthase (CS EC 2.3.3.1), the leaves were homogenized using $100 \mathrm{mM}$ Tris- $\mathrm{HCl}$ buffer $\mathrm{pH}$ 8.2, containing $5 \mathrm{mM} \beta$-mercaptoethanol (SigmaAldrich, St. Louis, MO, USA), $1 \mathrm{mM} \mathrm{Na} \mathrm{NaDTA}$ and $10 \%$ glycerol. The leaves were filtered and centrifuged as reported [54]. All steps were performed at $4^{\circ} \mathrm{C}$. The CS enzyme was assayed adding $50 \mathrm{~mL}$ of oxalacetic acid $0.17 \mathrm{mM}, 50 \mathrm{~mL}$ acetyl-CoA $0.2 \mathrm{mM}$, and $10 \mathrm{~mL}$ extract, to $3 \mathrm{~mL}$ of Tris- $\mathrm{HCl} 0.1 \mathrm{M}(\mathrm{pH} 8.0)$. This activity was measured spectrophotometrically at $25^{\circ} \mathrm{C}$, by monitoring the reduction of acetyl-coenzyme A (acetyl-CoA) to CoA, at wavelength $\mathrm{A}_{232}$. The activity was expressed as unit per milligramme protein. One unit corresponds to the reduction of $1 \mu \mathrm{mol}$ of acetyl-CoA per minute at $30^{\circ} \mathrm{C}$.

To extract $\mathrm{NADP}^{+}$-isocitrate dehydrogenase $\left(\mathrm{NADP}^{+}\right.$IDH EC 1.1.1.42) and MDH (EC 1.1.1.37), the leaves were homogenized using $100 \mathrm{mM}$ Tris- $\mathrm{HCl}$ buffer $\mathrm{pH} 8.2$ containing $5 \mathrm{mM} \beta$-mercaptoethanol (Sigma), $1 \mathrm{mM}$ $\mathrm{Na}_{2}$ EDTA and $10 \%$ glycerol. The extracts were filtered and centrifuged as reported [54]. All steps were performed at $4^{\circ} \mathrm{C}$.

For $\mathrm{NADP}^{+}$-IDH activity, $50 \mu \mathrm{L}$ of crude extract was added to 2.85 final volume of a reaction mixture containing $88 \mathrm{mM}$ imidazole buffer ( $\mathrm{pH} 8.0$ ), $3.5 \mathrm{mM} \mathrm{MgCl}_{2}$, $0.41 \mathrm{mM} \beta$-NADP-Na salt and $0.55 \mathrm{mM}$ isocitrate- $\mathrm{Na}$ salt. The assay was performed at $25^{\circ} \mathrm{C}$ following the formation of $\operatorname{NADP}(\mathrm{H})$ at $\mathrm{A}_{340}$ [55]. The activity was expressed as unit per milligramme protein. One unit corresponds to the production of $1 \mu \mathrm{mol}$ of $\operatorname{NADP}(\mathrm{H})$ per minute. 
For MDH activity, $3.17 \mathrm{~mL}$ of assay mixture contained 94.6 $\mathrm{mM}$ phosphate buffer ( $\mathrm{pH}$ 6.7), $0.2 \mathrm{mM} \beta-\mathrm{NADH}$ $\mathrm{Na}_{2}$ salt, $0.5 \mathrm{mM}$ oxalacetic acid, and $1.67 \mathrm{mM} \mathrm{MgCl}_{2}$. $\mathrm{MDH}$ activity was assayed at $25^{\circ} \mathrm{C}$, following the formation of $\mathrm{NAD}^{+}$at $\mathrm{A}_{340}$ [54]. The activity was expressed as unit per milligramme protein. One unit corresponds to the production of $1 \mu \mathrm{mol}$ of $\mathrm{NAD}^{+}$per minute.

\section{Free amino acids determination}

The free amino acids were analyzed, as by the method of Seebauer et al. [56]. Fifty milligrammes of homogenous dry powder was extracted for $1 \mathrm{~h}$ at room temperature with $1.5 \mathrm{~mL}$ of a $5 \%(w / v)$ TCA solution. The sample was clarified by centrifugation, and $1.5 \mathrm{~mL}$ of the supernatant was analyzed for free amino acids. The amino acid analysis was accomplished by precolumn OPA derivatization of the sample followed by reverse phase separation, using an Agilent 1100 HPLC (Agilent Technologies, Palo Alto, CA, USA) equipped with a thermo-controlled auto-sampler, fluorescence detector and an Agilent HP Chemstation for data elaboration. The chromatographic conditions were described previously [57].

\section{RNA extraction and CDNA synthesis}

The tissue samples were ground in liquid nitrogen. Aliquots of approximately $100 \mathrm{mg}$ were used for RNA extraction using TRIzol reagent (Invitrogen, Carlsbad, CA, USA) according to the manufacturer's instructions. RNA was quantified by spectrophotometric reading, and the quality was assayed by agarose gel electrophoresis. After DNAse treatment (Promega, Milan, Italy), first-strand cDNA was synthesized from $5 \mu \mathrm{g}$ of total RNA using 200 U of MMLV Reverse Transcriptase (Promega, Milan, Italy) and oligo(dT) as a primer in $20 \mu \mathrm{L}$ reactions, as described by Sambrook and collaborators [58].

\section{Semi-quantitative RT-PCR analysis}

To determine the expression level of $N R$ (NCBI accession number M27821), AS (NCBI accession number X82849), $M D H$ (NCBI accession number T27564), CS (NCBI accession number W49861) and IDH (NCBI accession number W21690), semi-quantitative RT-PCR experiments with specific primers were performed as described earlier [59]. Genes analyzed and relative primers are listed in Table 1. The constitutively expressed 18S rRNA (NCBI; Accession Number U42796.1) gene was used as an internal control of RNA quantity. PCR products were separated by electrophoresis in a 1-2.5\% agarose gel stained with ethidium bromide, and quantified through the ImageJ program (Image $1.38 \mathrm{~J}$, Wayne Rasband, National Institute of Health, Bethesda, MD, USA). PCR reactions were performed on cDNAs obtained from two different RNA extractions from independent experiments and repeated at least three times for each cDNA. PCR products were further purified by using the QIAquick gel extraction Kit (Qiagen, Hilden, Germany) and sequenced, according to Sanger et al. [60], using the ABIPRISM original Rhodamine Terminator kit (Applied Biosystems, Branchburg, NJ, USA). The sequence comparisons were performed by using Blastx and Blastn computer programs (NCBI, National Center for Biotechnology Information).

\section{Statistical analysis}

All sets of experiments were repeated three times, and for each set three replicates were assayed. Data were the means of three replicates, and the standard deviations did not exceed 5\%. The results obtained were processed statistically by the Student-Newman-Keuls test [61].

\section{Results}

\section{Effects of HS treatments on plant growth}

After growing for 12 days in a complete nutrient solution, the plants were transferred in a solution containing two different concentrations of HS and treated for $48 \mathrm{~h}$. For

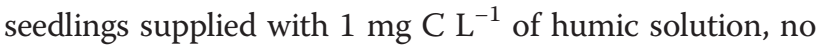
significant difference from control was found for leaves, roots length and fresh weight. Conversely, treatment with a greater humic concentration $\left(5 \mathrm{mg} \mathrm{C} \mathrm{L}^{-1}\right)$ produced length of both leaves and roots $8 \%$ shorter than the control seedlings (Figure 1a,b) and fresh weight (Figure 2a,b).

\section{Effects of HS treatments on protein content and enzyme activities}

The amount of proteins was always significantly lower in roots than in leaves of maize seedlings. Seedlings treated with $1 \mathrm{mg} \mathrm{C} \mathrm{L}^{-1}$ of HS showed a leaf content of protein larger than control (7\%). On the other hand, a significant decrease in protein content $(-21 \%)$ was observed in the leaves of seedlings supplied with $5 \mathrm{mg} \mathrm{C} \mathrm{L}^{-1} \mathrm{HS}$ (Figure 3a). In roots, no significant differences with respect to the

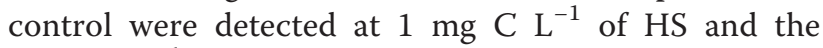
$5 \mathrm{mg} \mathrm{C} \mathrm{L}{ }^{-1}$ treatment even caused a $5 \%$ decrement in protein content (Figure $3 \mathrm{~b}$ ).

The humic addition to the growing medium affected the activities of NR and NiR in a concentration-dependent manner (Figure 4a,b). As for NR, the application of 1 and $5 \mathrm{mg} \mathrm{C} \mathrm{L}{ }^{-1}$ concentrations increased the NR specific activity by about $10 \%$ and $56 \%$, respectively (Figure $4 \mathrm{a}$ ). A similar behaviour was found for NiR activity. In plants

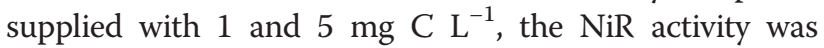
increased by $12 \%$ and $41 \%$, respectively (Figure $4 \mathrm{~b}$ ).

The GS and NADH-GOGAT enzymes showed a doseresponse activity similar to those described for NR and NiR. When maize seedlings were supplied with $\mathrm{HS}$ at 1 and $5 \mathrm{mg} \mathrm{C} \mathrm{L}^{-1}$, GS and GOGAT activities increased by $11 \%$ and $30 \%$, and by $64 \%$ and $92 \%$ respectively (Figure 5a,b). 
Table 1 Specific forward and reverse primer sequences used in semi-quantitative RT-PCR

\begin{tabular}{llll}
\hline Gene & Primer forward (5'-3') & Primer reverse (5'-3') & Accession number \\
\hline NR (nitrate reductase) & 5'-TTCATGAACACTACCGACGTCG-3' & 5'-GAGCCTGTACGGATACTCGGC-3' & M27821 \\
AS (asparagine synthetase) & 5'-CATCATTGAGCTCTCGCGCAGGTTAC-3' & 5'-GGGGGAAATGTTATGAAGCGTTCACAA-3' & X82849 \\
CS (citrate synthetase) & 5'-GTTTGGTCATGGAGTTCTGCGTAA-3' & 5'-GGAGGTACAACTTCATACAACTTGGACAC-3' & W49861 \\
IDH (isocitrate dehydrogenase) & 5'-AAACTCGAGGCTGCTTGCGTTGAGA-3' & 5'-ATAATTAGCTTGCATCGAAACTGCGG-3' & W21690 \\
MDH (malate dehydrogenase) & 5'-GCCAGATTTCTGAGAGACTTAATGTCCA-3' & 5'-TCGAGGCATGAGTAAGCAAGCGTCTT-3' & T27564 \\
I8S & 5'-CCATCCCTCCGTAGTTAGCTTCT-3' & 5'-CCTGTCGGCCAAGGCTATATAC-3' & U42796.1 \\
\hline
\end{tabular}

As for AspAT, the plants supplied with 1 and $5 \mathrm{mg} \mathrm{C}$ $\mathrm{L}^{-1}$ of $\mathrm{HS}$ showed an increase in enzyme activity of $16 \%$ and $20 \%$, respectively (Figure $6 \mathrm{a}$ ). Conversely, the AS activity had a different trend, since $1 \mathrm{mg} \mathrm{C} \mathrm{\textrm {L } ^ { - 1 }}$ caused a decrease in the AS activity $(-15 \%)$ and $5 \mathrm{mg}$ $\mathrm{C} \mathrm{L} \mathrm{L}^{-1}$ of $\mathrm{HS}$ caused a significant larger stimulation (+18\%) compared to the control (Figure 6b).

We evaluated the effects of $\mathrm{HS}$ on $\mathrm{CS}, \mathrm{NADP}^{+}$-IDH and $\mathrm{MDH}$ of maize seedlings because of their important role in maintaining the balance between $\mathrm{C}$ and $\mathrm{N}$ metabolism. When plants were supplied with $\mathrm{HS}$ at 1 and $5 \mathrm{mg} \mathrm{C} \mathrm{L} \mathrm{L}^{-1}$, an increase of CS activity by $56 \%$ and $98 \%$, respectively, was observed in comparison to the control (Figure 7a). A similar trend was also observed for $\mathrm{NADP}^{+}$-IDH and $\mathrm{MDH}$ activities (Figure 7b,c). The seedlings treated with 1 and $5 \mathrm{mg} \mathrm{C} \mathrm{L}^{-1}$ showed an increase of both $\mathrm{MDH}$ and $\mathrm{NADP}^{+}$-IDH activities by $14 \%$ and $20 \%$, and $93 \%$ and $81 \%$, respectively.

\section{Effect of HS treatment on the amino acid content}

The free amino acid content in leaves was measured to follow HS effects on nitrogen assimilation. Aspartate (Asp), threonine (Thr), isoleucine (Ile) and lysine (Lys) increased by $10 \%$ to $13 \%$ with $1 \mathrm{mg} \mathrm{C} \mathrm{L}^{-1} \mathrm{HS}$, while the $5 \mathrm{mg} \mathrm{C} \mathrm{\textrm {L } ^ { - 1 }}$ did not change the amino acids' content (Table 2). However, asparagine (Asn) behaved differently, as it was increased (41\%) only with the addition of $5 \mathrm{mg}$

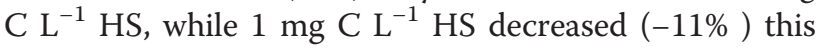
amino acid in leaves as compared to control.

\section{Effect of humic sample on gene expression}

To gain further insight on the mechanisms of regulation of the enzyme previously described by HS, the expression of five genes encoding the key enzymes of $\mathrm{N}$ assimilation and organic acids synthesis was evaluated in leaves of both nitrate-supplied and nitrate-depleted maize seedlings, in response to $1 \mathrm{mg} \mathrm{C} \mathrm{L}{ }^{-1} \mathrm{HS}$ for $24 \mathrm{~h}$. The transcript

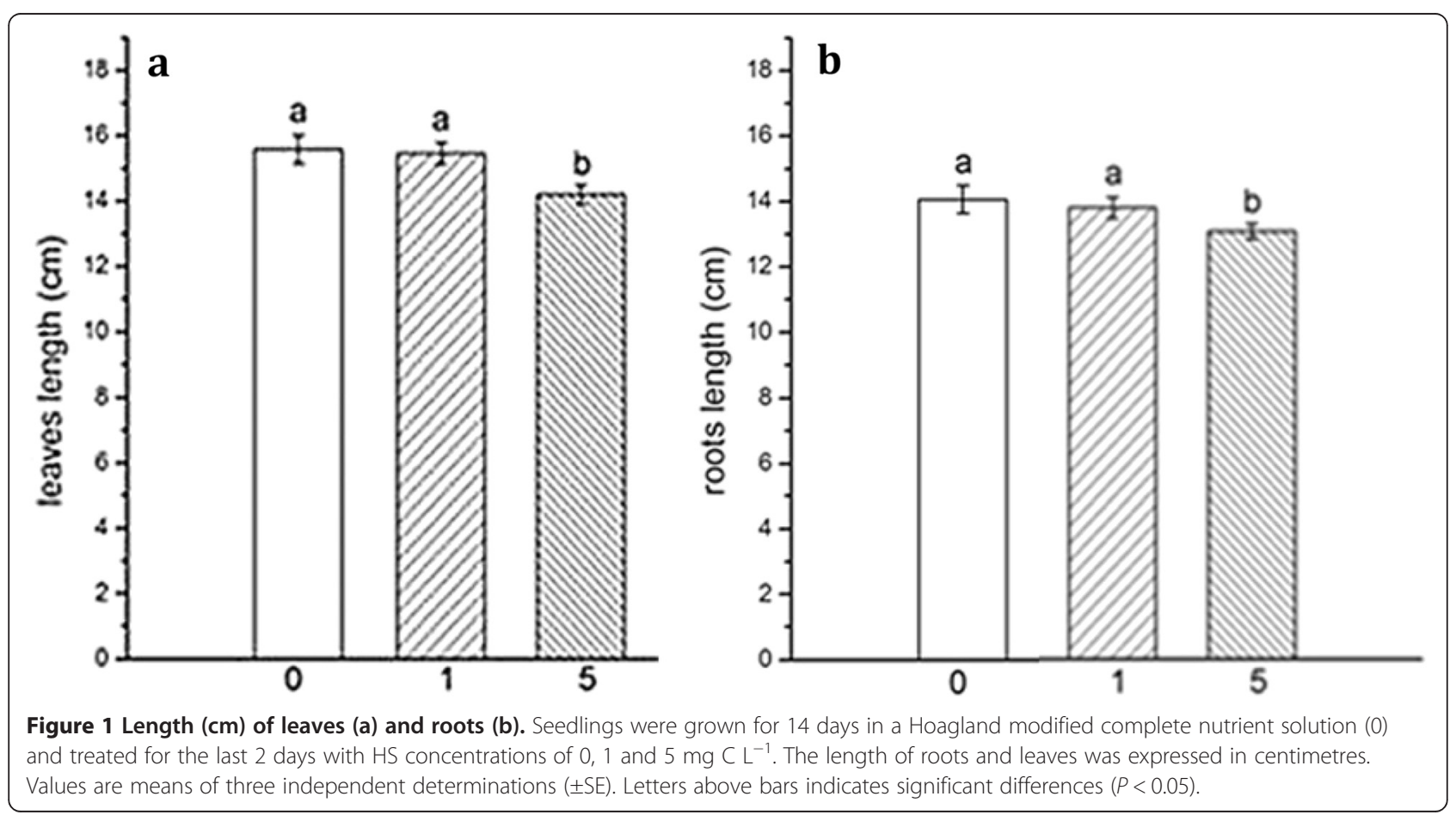




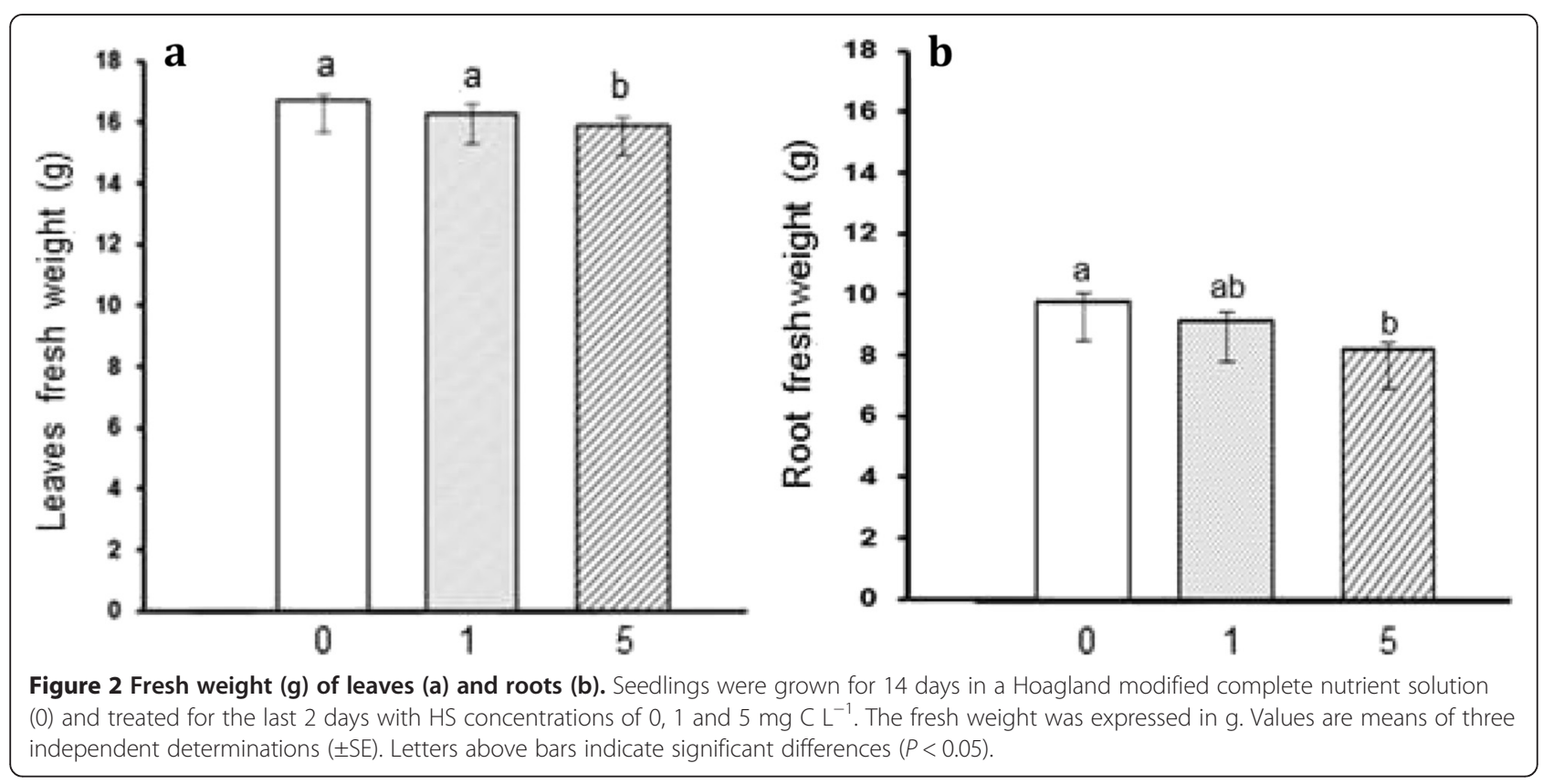

accumulation of the gene encoding a NADH-NR [59] showed a significant increase after the treatment with $1 \mathrm{mg}$ $\mathrm{C} \mathrm{L}^{-1} \mathrm{HS}$ in leaves of $\mathrm{N}$-supplied plants, with respect to that detected in leaves of $+\mathrm{N}$ control plants (Figure 8 ). Conversely, no NR transcript accumulation was observed in the leaves of N-deprived plants of either HS-treated or control seedlings. Similarly, humic treatment induced a substantial increase of mRNA abundance in leaves of N-supplied seedlings, whereas no significant differences were detected when N-depleted seedlings were supplied with HS.

A similar expression pattern in response to humic substances provision was also observed for the genes encoding $\mathrm{MDH}, \mathrm{CS}$ and IDH enzymes which are involved in the Krebs cycle and $\mathrm{N}$ organication. In the case of $\mathrm{MDH}$, a slight decrease of mRNA abundance was found in Ndeprived leaves after humic supply. Moreover, the transcript
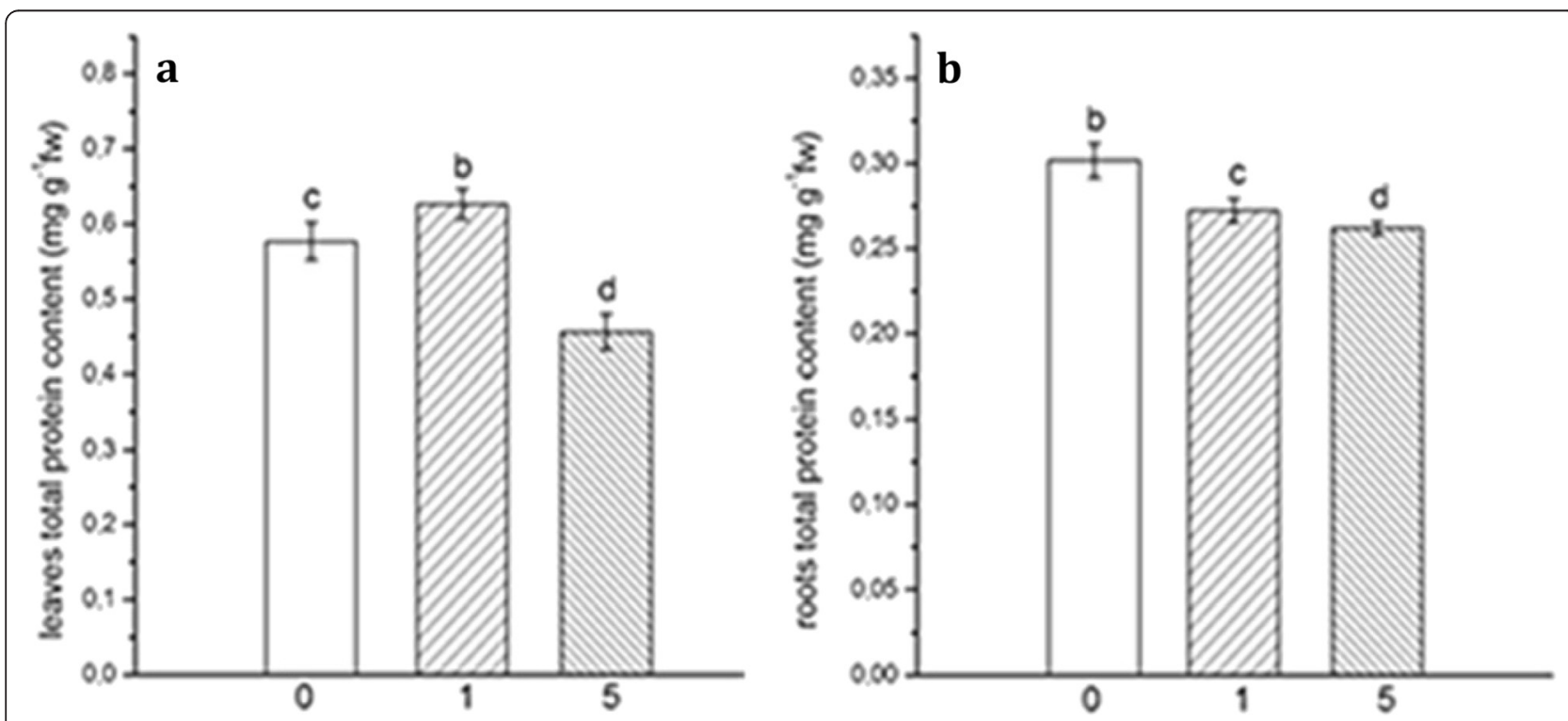

Figure 3 Total protein content in leaves (a) and roots (b). Seedlings were grown for 14 days in a Hoagland modified complete nutrient solution ( 0 ) and treated for the last 2 days with $\mathrm{HS}$ concentrations of 0,1 and $5 \mathrm{mg} \mathrm{C} \mathrm{L}^{-1}$. The protein concentration was expressed in milligrammes of protein per gramme of fresh weight. Values are means of three independent determinations $( \pm \mathrm{SE})$. Letters above bars indicates significant differences $(P<0.05)$. 


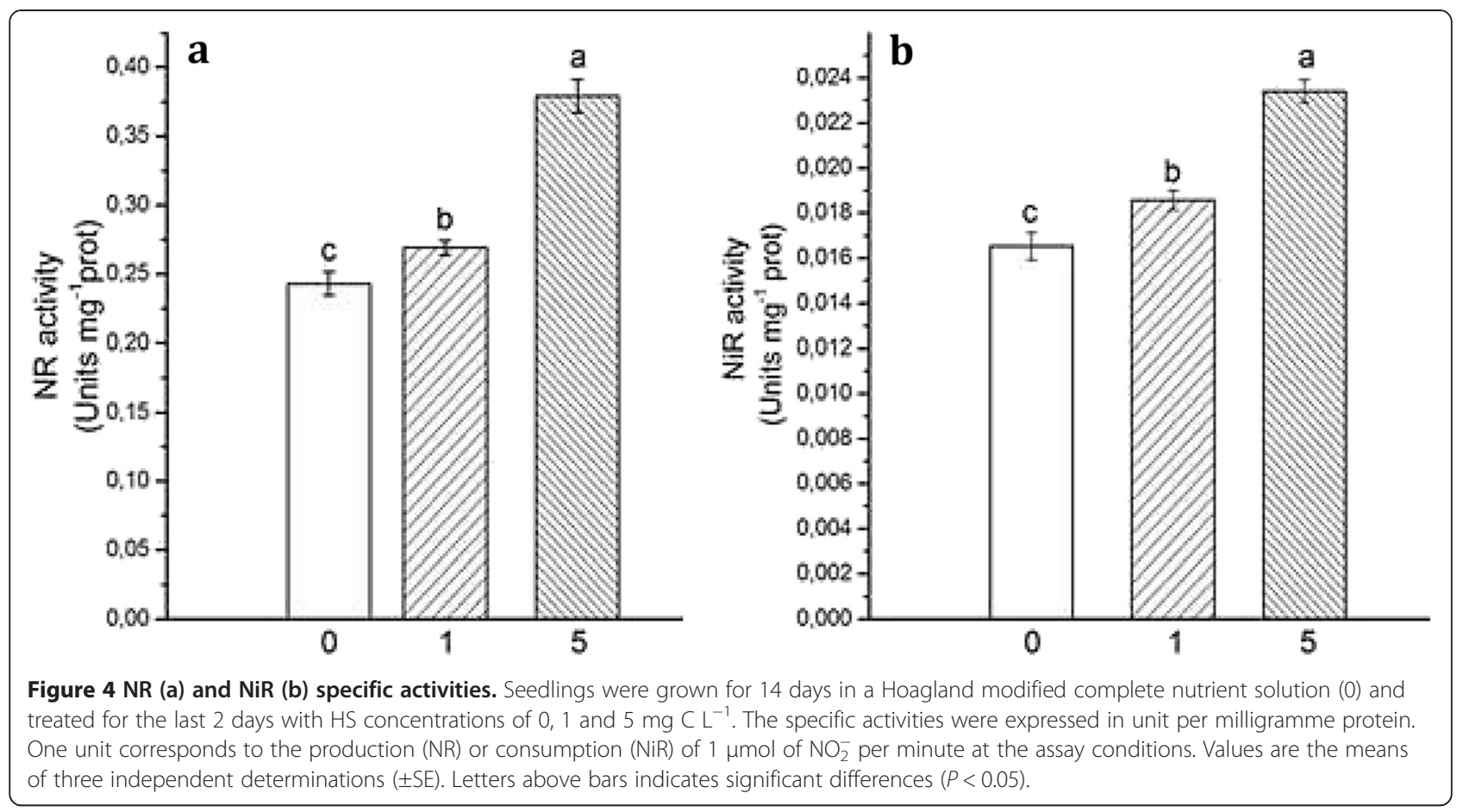

level of these three genes was always lower in $\mathrm{N}$ deficiency conditions in respect to that for $\mathrm{N}$-supplied plants.

\section{Discussion}

Since the 1980s, several studies have highlighted the existence of biological effects of HS on plant physiology and metabolism $[1,3,6,25,32]$. However, only more recently, the attention of researchers has been focused on HS fractions characterized by an apparently low-molecularweight (LMW), which seems to influence plant growth and physiology more than other fractions $[3,63]$. In fact, several works focused on effects of LMW fraction on

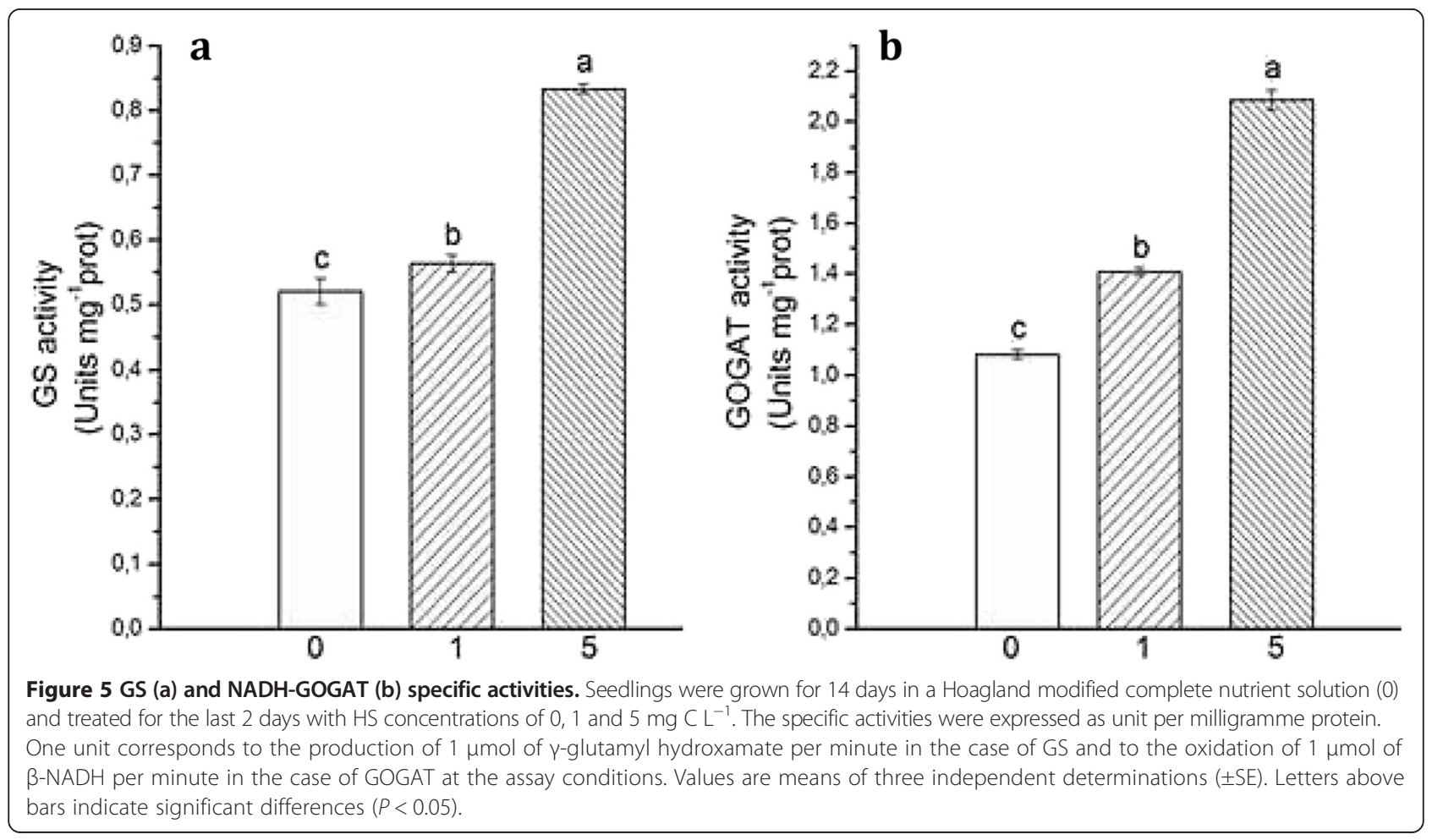




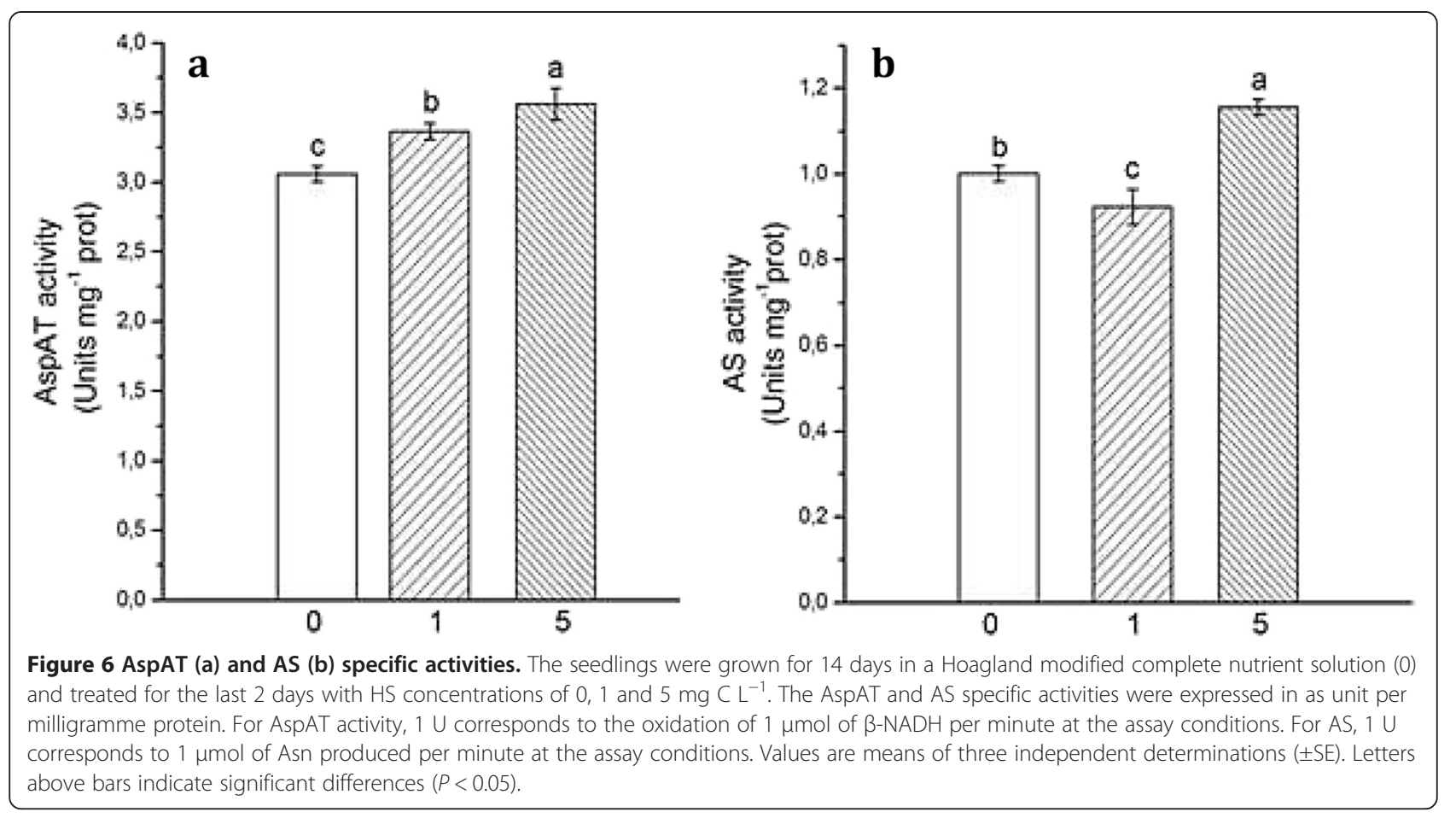

nitrogen uptake $[33,34,37,64]$ and assimilation [65], but the results obtained were often contradictory [66,67]. Their positive effects have mainly been attributed to a large content of carbohydratic and carboxyl-C groups [32,68].

More recently, Nardi and coworkers [36] evaluated the effect on the respiratory metabolism of maize seedlings provided by different size fractions of a soil humic acid, after their separation by preparative high-performance size-exclusion chromatography (HPSEC). The evaluation of the biological activity of size fractions showed that the size fraction with the smallest molecular size was more bioactive, followed by, in the order of, both the original bulk humic acid and the larger size fractions. Such effect was attributed to the larger flexibility of the smallest size fraction conferred by its greater content of hydrophilic components [36]. In fact, both the conformational flexibility and the hydrophilicity of this small-sized humic fraction should facilitate the release from its supramolecular structure upon the action of organic acids exuded by roots of humic molecules with plant stimulation activity. The diffusion of such bioactive molecules in solution should be less easy from humic matrices with larger and more compact conformations $[37,38,69]$. Here, we used the same bulk humic acid that was found bioactive and second only to its separated smallest size fractions in order to evaluate its effects on nitrogen assimilation in maize at both physiological and molecular levels. This species was chosen because of its worldwide economic and agronomic importance and also because of its importance as a model plant [70].
Our results indicate that the HS treatment influenced the activities of all these enzymes in a dose-dependent manner. In particular, the increase of enzyme activity in relation to the dose of HS supplied was exponential as a significant stimulation was observed when plants were treated with $5 \mathrm{mg} \mathrm{C} \mathrm{L}{ }^{-1}$. A different trend was observed for AS, because its specific activity was strongly stimulated

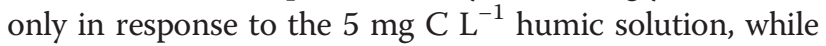
it was slightly inhibited by the $1 \mathrm{mg} \mathrm{C} \mathrm{L}^{-1}$ treatment.

The synthesis of Asn is in competition with that of Asp, Lys, Thr and Ile, which represent, together with the amino acids of the aspartate family [71], the main substrates for the synthesis of structural proteins and enzymes required for the optimal plant development [72]. However, Asn may also represent a transitory store of $\mathrm{N}$ to be later used to meet specific demands during plant growth [73]. Our results showed a significantly higher accumulation of Lys, Ile and Thr in leaves of seedlings grown with $1 \mathrm{mg} \mathrm{C} \mathrm{L} \mathrm{L}^{-1}$ of HS in comparison to those observed in control plants that is in accordance with the higher content of soluble proteins measured in HS-treated leaves.

To deepen the understanding of molecular events underlying the HS effects on plant physiology, the expression of five genes encoding the enzymes involved in few key steps of $\mathrm{N}$ assimilation was evaluated. To discriminate $\mathrm{N}$-dependent from $\mathrm{N}$-independent molecular effects of HS, the transcript amount was measured in leaves of both nitrate-supplied and nitrate-depleted HS-treated seedlings. In this case, the choice of a 24-h treatment was aimed at evaluating the earlier molecular effects of 

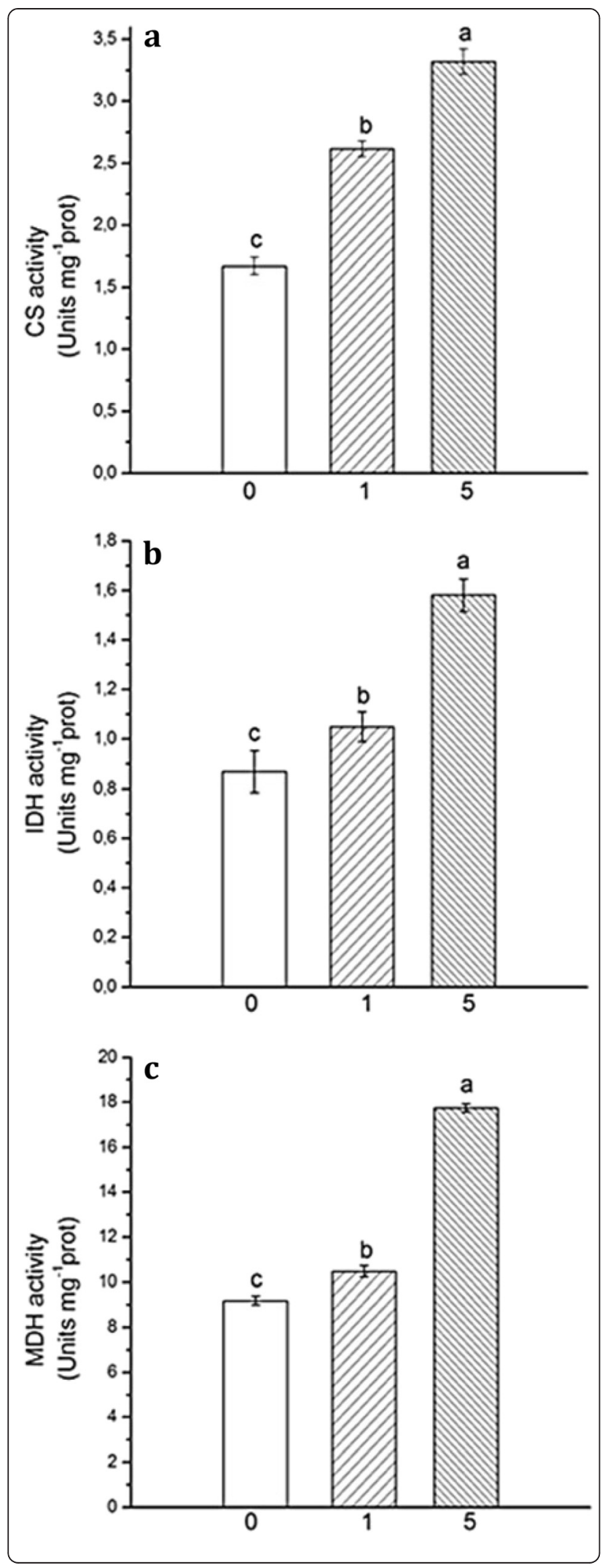

Figure 7 CS (a), NADP ${ }^{+}$IDH (b) and MDH (c) specific activities. The seedlings were grown for 14 days in a Hoagland modified complete nutrient solution (0) and treated for the last 2 days with $\mathrm{HS}$ concentrations of 0,1 and $5 \mathrm{mg} \mathrm{CL^{-1 }}$. The specific activities were expressed unit per milligramme protein. For $C S, 1 \mathrm{U}$ corresponds to the reduction of $1 \mu \mathrm{mol}$ Ac-CoA per minute; for $\mathrm{NADP}^{+}-\mathrm{IDH}, 1 \mathrm{U}$ corresponds to $1 \mu \mathrm{mol}$ of $\mathrm{NADPH}$ reduced per minute and for $\mathrm{MDH}$ to $1 \mu \mathrm{mol}$ of $\mathrm{NAD}^{+}$formed per minute at assay conditions. Values are means of three independent determinations $( \pm \mathrm{SE}$ ). Letters above bars indicate significant differences $(P<0.05)$.

humic matter. In fact, Trevisan et al. [40] showed that the gene transcription in response to HS is regulated already after a few hours of treatment.

Our findings show an increase of mRNA abundance of all genes therein studied upon HS treatment only when seedlings were grown in the presence of nitrate. On the contrary, HS did not induce any increase of transcript accumulation when the nutrient solution was depleted of nitrate. These results globally suggest that the enzyme stimulation observed after the humic supply may be generally regulated at the transcriptional level. An exception seems to be represented by the expression of the AS gene that was strongly induced after $24 \mathrm{~h}$ of treatment with $1 \mathrm{mg} \mathrm{C} \mathrm{L}{ }^{-1}$ solution, whereas the AS activity measured after $48 \mathrm{~h}$ was lower than for the control. This may be due either to a more rapid down-regulation of the AS activity in response to the duration of HS treatment or otherwise to the occurrence of some post-transcriptional regulatory mechanisms. Furthermore, since most of the genes analyzed are nitrate-responsive, it may be hypothesized that the HS regulation of the transcription of genes involved in nitrogen metabolism may be mediated by a nitratedependent signal, since HS' stimulatory effect is evident only when the nutrient solution contained nitrate.

\section{Conclusions}

Our results indicate a positive dose-dependent effect of the humic acid used here on the activities of the main enzymes involved in the reduction and assimilation of inorganic nitrogen. The enhanced bioactivity of HS may

Table 2 Amino acid contents ( $\mu \mathrm{mol} \mathrm{g}^{-1} \mathrm{fw}$ ) in leaves

\begin{tabular}{llll}
\hline Amino acid & \multicolumn{3}{l}{ Treatment } \\
\cline { 2 - 4 } & $\mathbf{C}$ & $\mathbf{1}$ & $\mathbf{5}$ \\
\hline Aspartate & $1.74 \pm 0.3$ & $1.97 \pm 0.52$ & $1.8 \pm 0.45$ \\
Threonine & $2.78 \pm 0.92$ & $3.06 \pm 0.96$ & $2.76 \pm 0.92$ \\
Isoleucine & $1.31 \pm 0.27$ & $1.46 \pm 0.35$ & $1.3 \pm 0.62$ \\
Lysine & $1.36 \pm 0.32$ & $1.53 \pm 0.47$ & $1.3 \pm 0.31$ \\
Asparagine & $1.7 \pm 0.4$ & $1.55 \pm 0.18$ & $2.4 \pm 0.39$ \\
Glutamate & $2.85 \pm 0.90$ & $3.19 \pm 0.96$ & $2.71 \pm 0.52$
\end{tabular}

Seedlings were grown for 14 days in a Hoagland modified complete nutrient solution ( 0 ) and treated for the last 2 days with HS concentrations of 0,1 and $5 \mathrm{mg}$ $\mathrm{CL}^{-1}$. Mean values $\pm \mathrm{SD}$ were obtained from five independent measurements. 


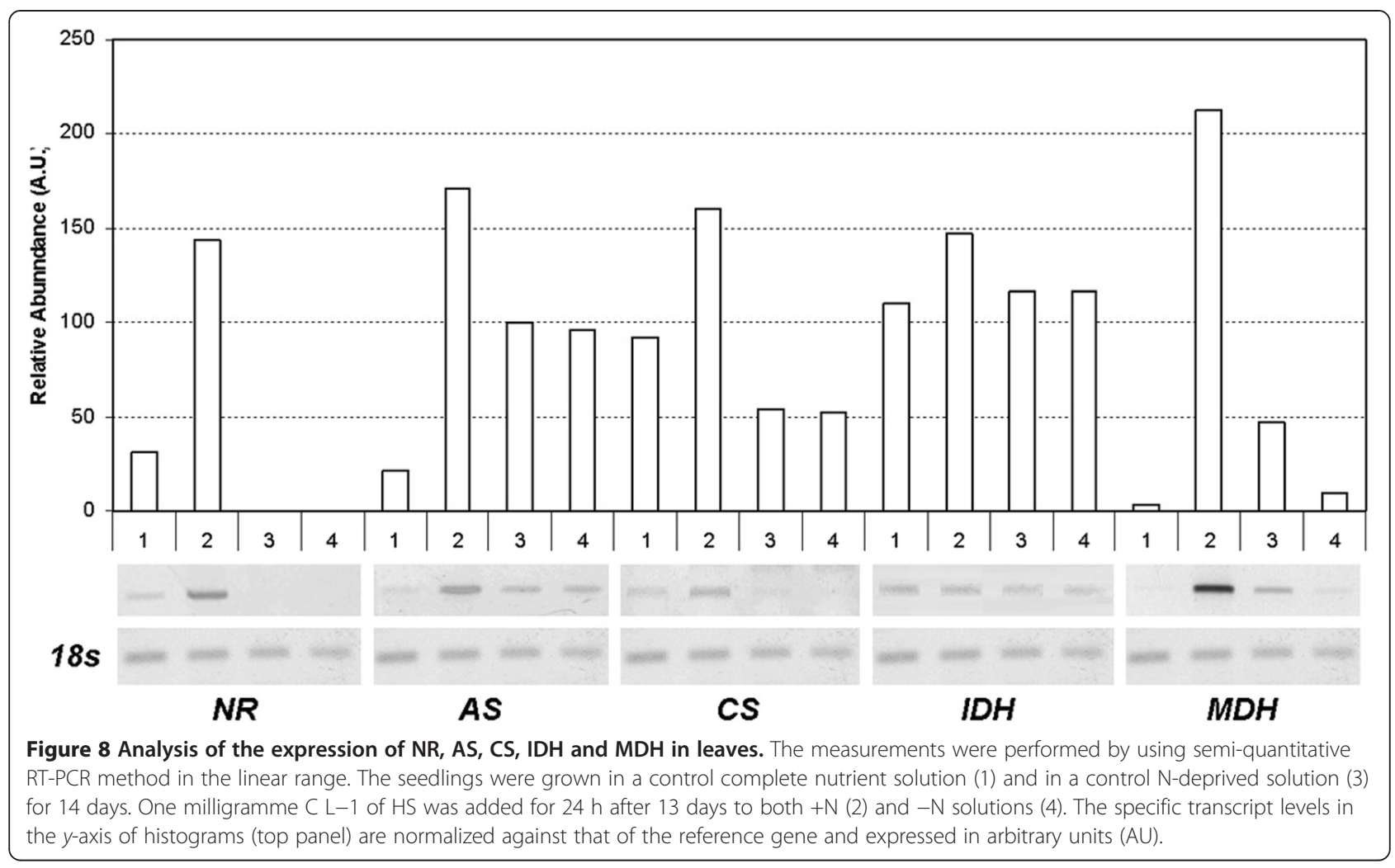

be explained with the tendency to increase the size of supramolecular aggregation of humic molecules with concentration [74] and the concomitant enhanced capacity to provide specific bioactive molecules to targeted root cell membranes [6].

Among all enzymes, only the AS showed a different trend of regulation in response to HS, possibly because of a competition of its own substrate with the biosynthesis of amino acids of the Asp family [75], thus favouring the accumulation of a large amount of Asn in seedling leaves treated with the greatest HS concentration. This is not surprising considering that Asn accumulation in young leaves is an indirect result of the restriction of protein synthesis when the metabolism is subjected to stress conditions [73]. While further studies should be certainly conducted to increase our understanding on the doseresponse of HS, molecular findings suggest that the biochemical response to humic treatments may principally depend on a transcriptional mechanism of regulation, as previously hypothesized for the regulation of a maize isoform of $\mathrm{H}^{+}$-ATPase [34] and with a more holistic approach by Trevisan et al. [46]. However, the induction of a gene expression in response to HS seems to depend closely on the presence of nitrate in the growing medium because humic matter alone was not able to up-regulate the transcription of genes. These findings suggest that HS may act as an additional signal in the regulation of gene expression mediated by nitrate, by either promoting its bioavailability or interfering with the signalling pathway that leads plants to adapt their metabolism to the nutrient availability $[64,76]$.

\section{Competing interests}

The authors declare that they have no competing interests.

\section{Authors' contributions}

SV carried out the molecular genetic studies and participated in drafting the manuscript. AE participated in drafting the manuscript and made the corrections. AN participated in drafting the manuscript. AM, AP and SN conceived of the study, participated in its design and coordination and helped draft the manuscript. SQ carried out the molecular genetic studies and participated in drafting the manuscript. All authors read and approved the final manuscript.

\section{Acknowledgements}

This work was partially supported by the project COFIN 2003 no. 2003071271 funded by the Italian Ministry of University and Research (MIUR).

\section{Author details}

'Department of Agronomy, Food, Natural Resources, Animal and Environment, University of Padua, Agripolis - Viale dell'Università, 16, Legnaro, Padua 35020, Italy. ${ }^{2}$ Centro Interdipartimentale di Ricerca sulla Risonanza Magnetica Nucleare per l'Ambiente, l'Agro-Alimentare ed i Nuovi Materiali (CERMANU), Università di Napoli Federico II, Via Università 100, Portici 80055, Italy. ${ }^{3}$ Agriculture Department, Mediterranea University of Reggio Calabria, Feo di Vito, Reggio Calabria 89060, Italy.

Received: 29 November 2014 Accepted: 20 January 2015

Published online: 13 February 2015

\section{References}

1. Vaughan D, Malcom RE (1985) Influence of humic substances on growth and physiological processes. In: Vaughan D, Malcom RE (ed) Soil organic matter and biological activity. Martinus Nijhoff/Junk W, Dordrecht, pp 37-76 
2. Piccolo A (1996) Humic substances in terrestrial ecosystems. Elsevier, Amsterdam, pp 225-264

3. Nardi S, Carletti P, Pizzeghello D, Muscolo A (2009) Biological activities of humic substances. In: Senesi N, Xing B, Huang PM (ed) Biophysico-chemical processes involving natural nonliving organic matter in environmental systems. Part I. Fundamentals and impact of mineral-organic-biota interactions on the formation, transformation, turnover, and storage of natural nonliving organic matter (NOM). Wiley, Hoboken, pp 305-339

4. Muscolo A, Sidari M, Nardi S (2013) Humic substance: relationship between structure and activity. Deeper information suggests univocal findings. J Geochem Explor 129:57-63

5. Nardi S, Pizzeghello D, Reniero F, Rascio N (2000) Chemical and biochemical properties of humic substances isolated from forest soils and plant growth. Soil Sci Soc Am J 64:639-645

6. Canellas LP, Olivares FL (2014) Physiological responses to humic substances as plant growth promoter. Chem Biol Technol Agric 1:1-11

7. Horrigan L, Lawrence RS, Walker P (2002) How sustainable agriculture can address the environmental and human health harms of industrial agriculture. Environ Health Persp 110:445-456

8. Smith EG, Young DL (2000) The economic and environmental revolution in semi-arid cropping in North America. Annal Arid Zone 39:347-361

9. Hirel B, Le Gouis J, Ney B, Gallais A (2007) The challenge of improving nitrogen use efficiency in crop plants: towards a more central role for genetic variability and quantitative genetics within integrated approaches. J Exp Bot 58:2369-2387

10. Stevenson FJ (1994) Humus chemistry: genesis, composition, reactions, 2nd edition. Wiley, New York

11. Piccolo A (2002) The supramolecular structure of humic substances. A novel understanding of humus chemistry and implications in soil science. Adv Agron 75:57-134

12. Piccolo A, Conte P, Spaccini R, Chiarella P (2003) Effects of some dicarboxylic acids on the association of dissolved humic substances. Biol Fert Soils 37:255-259

13. Piccolo A, Conte P, Cozzolino A (2001) Chromatographic and spectrophotometric properties of dissolved humic substances compared with macromolecular polymers. Soil Sc 166:174-185

14. Orsi M (2014) Molecular dynamics simulation of humic substances. Chem Biol Technol Agric 1:1-14

15. Beiraghi A, Pourghazi K, Amoli-Diva M (2014) Mixed supramolecular hemimicelles aggregates and magnetic carrier technology for solid phase extraction of ibuprofen in environmental samples prior to its HPLC-UV determination. Chem Eng Sci 108:103-110

16. Nebbioso A, Piccolo A (2011) Basis of a humeomics science: chemical fractionation and molecular characterization of humic biosuprastructures. Biomacromolecules 12:1187-1199

17. Nebbioso A, Piccolo A (2012) Advances in humeomic: enhanced structural identification of humic molecules after size fractionation of a soil humic acid. Anal Chim Acta 720:77-90

18. Nebbioso A, Piccolo A, Lamshoft M, Spiteller M (2014) Molecula characterization of an end-residue of humeomics applied to a soil humic acid. RSC Adv 4:23658-23665

19. Niklewski B, Woiciechowski J (1937) Uber den Einfluss der wasserlöslichen Humusstoffe auf die Entwicklung einiger Kulturpflanzen. Z. Pflanzenernaehr Dueng. Bodenkd 49:294-327

20. Čatsky J (1958) Uber den Einfluss der Oxy humolithen auf die mineralische Ernährung der Pflanzen. Folia Biol 4:443-448

21. Khristeva LA, Gallushko AM, Gorovaya Al, Kolbassin AA, Shortshoi LP, Tkatshenko LK, Fot LW, Luk'Yakenko NV (1980) The main aspects of using physiologically active substances of humus nature. VI International Peat Congress, Minnesota

22. Nardi S, Concheri G, Dell'Agnola G (1996) Biological activity of humic substances. In: Piccolo A (ed) Humic substances in terrestrial ecosystems. Elsevier, Amsterdam, pp 361-406

23. Vaughan D, Linehan DJ (1976) The growth of wheat plants in humic acid solutions under axenic conditions. Plant Soil 44:445-449

24. Varanini Z, Pinton R (1995) Humic substances and plant nutrition. In: Behnke HD et al. (ed) Progress in botany, vol 56. Springer, Berlin, pp 97-117

25. Varanini Z, Pinton R (2001) Direct versus indirect effects of soil humic substances on plant growth and nutrition. In: Pinton R et al. (ed) The rizosphere. Marcel Dekker, Basel, pp 141-158
26. Nardi S, Concheri G, Pizzeghello D, Sturaro A, Rella R, Parvoli G (2000) Soil organic matter mobilization by root exudates. Chemosphere 41:653-658

27. Vaccaro S, Muscolo A, Pizzeghello D, Spaccini R, Piccolo A, Nardi S (2009) Effect of a compost and its water-soluble fractions on key enzymes of nitrogen metabolism in maize seedlings. J Agric Food Chem 57:11267-11276

28. Sladky Z (1959) The effects of extracted humus substances on growth of tomato plants. Biolol Plant 1:142-150

29. Vaughan D (1967) Effect of humic acid on the development of invertase activity in slices of beetroot tissues washed under aseptic conditions. Humus et Planta 4:268-271

30. Ferretti M, Ghisi R, Nardi S, Passera C (1991) Effect of humic substances on photosynthetic sulfate assimilation in maize seedlings. Can J Soil Sci 71:239-242

31. Nardi S, Concheri G, Dellagnola G, Scrimin P (1991) Nitrate uptake and ATPase activity in oat seedlings in the presence of 2 humic fractions. Soil Biol Biochem 23:833-836

32. Piccolo A, Nardi S, Concheri G (1992) Structural characteristics of humic substances as related to nitrate uptake and growth-regulation in plantsystems. Soil Biol Biochem 24:373-380

33. Canellas LP, Olivares FL, Okorokova-Facanha AL, Facanha AR (2002) Humic acids isolated from earthworm compost enhance root elongation, lateral root emergence, and plasma membrane $\mathrm{H}+$-ATPase activity in maize roots. Plant Physiol 130:1951-1957

34. Quaggiotti S, Ruperti B, Pizzeghello D, Francioso O, Tugnoli V, Nardi S (2004) Effect of low molecular size humic substances on nitrate uptake and expression of genes involved in nitrate transport in maize (Zea mays L.). J Exp Bot 55:803-813

35. Muscolo A, Sidari M, Attinà E, Francioso O, Tugnoli V, Nardi S (2007) Biological activity of humic substances is related to their chemical structure. Soil Sci Soc Am J 71:75-85

36. Nardi S, Muscolo A, Vaccaro S, Baiano S, Spaccini R, Piccolo A (2007) Relationship between molecular characteristics of soil humic fractions and glycolytic pathway and krebs cycle in maize seedlings. Soil Biol Biochem 39:3138-3146

37. Canellas LP, Piccolo A, Dobbss LB, Spaccini R, Olivares FL, Zandonadi DB, Façanha AR (2010) Chemical composition and bioactivity properties of size-fractions separated from a vermicompost humic acid. Chemosphere 78:457-466

38. Canellas LP, Dantas DJ, Aguiar NO, Peres LEP, Zsögön A, Olivares FL, Dobbss LB, Façanha AR, Nebbioso A, Piccolo A (2011) Probing the hormonal activity of fractionated molecular humic components in tomato auxin mutants. Ann Appl Biol 159:202-211

39. Pizzeghello D, Francioso O, Ertani A, Muscolo A, Nardi S (2012) Isopentenyladenosine and cytokinin-like activity of four humic substances. J Geochem Explor 129:103-111

40. Trevisan S, Pizzeghello D, Ruperti B, Francioso O, Sassi A, Palme K, Quaggiotti S, Nardi S (2010) Humic substances induce lateral root formation and expression of the early auxin-responsive IAA19 gene and DR5 synthetic element in Arabidopsis. Plant Biol 12:604-614

41. Trevisan S, Botton A, Vaccaro S, Vezzaro A, Quaggiotti S, Nardi S (2011) Humic substances affect Arabidopsis physiology altering the expression of genes involved in primary metabolism, growth and development. EEB 74:45-55

42. Zancani M, Petrussa E, Krajňáková J, Casolo V, Spaccini R, Piccolo A, Macrì F, Vianello A (2009) Effect of humic acids on phosphate level and energetic metabolism of tobacco BY-2 suspension cell cultures. Env Exp Bot 65:287-295

43. Zancani M, Bertolini A, Petrussa E, Krajňáková J, Piccolo A, Spaccini R, Vianello A (2011) Fulvic acid affects proliferation and maturation phases in Abies cephalonica embryogenic cells. J Plant Physiol 168:1226-1233

44. Muscolo A, Cutrupi S, Nardi S (1998) IAA detection in humic substances. Soil Biol Biochem 30:1199-1201

45. Russell L, Stokes AR, Macdonald H, Muscolo A, Nardi S (2006) Stomatal responses to humic substances and auxin are sensitive to inhibitors of phospholipase A(2). Plant Soil 283:175-185

46. Piccolo A, Conte P, Trivellone E, Van Lagen B, Buurman P (2002) Reduced heterogeneity of a lignite humic acid by preparative HPSEC following interaction with an organic acid. Characterization of size-separates by PYR-GC-MS and 1H-NMR spectroscopy. Envir Sci Technol 36:76-84

47. Nardi S, Sessi E, Pizzeghello D, Sturaro A, Rella R, Parvoli G (2002) Biological activity of soil organic matter mobilized by root exudates. Chemosphere 46:1075-1081 
48. Bradford MM (1976) A rapid and sensitive method for the quantitation of microgram quantities of protein utilizing the principle of protein-dye binding. Anal Biochem 72:248-254

49. Lewis OAM, James DM, Hewitt EJ (1982) Nitrogen assimilation in barley (Hordeum vulgare L. cv. Mazurka) in response to nitrate and ammonium nutrition. Ann Bot 49:39-49

50. Lillo C (1984) Diurnal variations of nitrite reductase, glutamine synthetase, glutamate synthase, alanine aminotransferase and aspartate aminotransferase in barley leaves. Physiol Plant 61:214-218

51. Cánovas FM, Cantón FR, Gallardo F, García-Gutiérrez A, De Vicente A (1991) Accumulation of glutamine synthetase during early development of maritime pine (Pinus pinaster) seedlings. Planta 185:372-378

52. Rej R, Horder M (1983) Aspartate aminotransferase (glutamate oxaloacetate transaminase). In: Methods of enzymatic analysis, 3rd edition. Bergmeyer, H. U, Weinheim

53. Lima JD, Sodek L (2003) N-stress alters aspartate and asparagine levels of xylem sap in soybean. Plant Sci 165:649-656

54. Bergmeyer HU (1986) In: Bergmeyer J, Marianne G (ed) Methods of enzymatic analysis. Weinheim, Basel

55. Goldberg DM, Ellis G (1986) Isocitrate. In: Bergmeyer HU (ed) Methods of enzymatic analysis. Academic, New York

56. Seebauer JR, Moose SP, Fabbri BJ, Crossland LD, Below FE (2004) Amino acid metabolism in maize earshoots. Implications for assimilate preconditioning and nitrogen signaling. Plant Physiol 136:4326-4334

57. Henderson JW, Ricker RD, Bidlingmeyer BA, Woodward C (2000) Rapid, accurate, sensitive and reproducible analysis of amino acids. Agilent Publication Number 5980-1193EN. Agilent Technologies, Palo Alto

58. Sambrook J, Fritsch EF, Maniatis F (1989) Molecular cloning: a laboratory manual, 2nd edition. Cold Spring Harbor Laboratory, Cold Spring Harbor New York

59. Quaggiotti S, Ruperti B, Borsa P, Destro T, Malagoli M (2003) Expression of a putative high-affinity $\mathrm{NO}_{3}^{-}$transporter and of an $\mathrm{H}+$-ATPase in relation to whole plant nitrate transport physiology in two maize genotypes differently responsive to low nitrogen availability. J Exp Bot 54:1023-1031

60. Sanger F, Nicklen S, Coulson AR (1977) DNA sequencing with chain-terminating inhibitors. PNAS 74:5463-5467

61. Sokal RR, Rohlf FJ (1969) Biometry, 1st edition. Freeman \& Co, San Francisco

62. Stevenson FJ (1994) Humus chemistry: genesis, composition, reactions, 2nd edition. Wiley, New York

63. Nardi S, Pizzeghello D, Muscolo A, Vianello A (2002) Physiological effects of humic substances on higher plants. Soil Biol Biochem 34:1527-1536

64. Pinton R, Cesco S, lacolettig G, Astolfi S, Varanini Z (1999) Modulation of $\mathrm{NO}_{3}^{-}$uptake by water-extractable humic substances: involvement of root plasma membrane $\mathrm{H}(+)$ ATPase. Plant Soil 215:155-161

65. Sessi E, Nardi S, Gessa C (2000) Effects of low and high molecular weight humic substances from two different soils on nitrogen assimilation pathway in maize seedlings. Humic Subst Environ 2:39-46

66. Malcolm RE, Vaughan D (1979) Humic substances and phosphatase activities in plant tissues. Soil Biol Biochem 11:253-259

67. Mato MC, Olmedo MG, Mendez J (1972) Inhibition of indoleacetic acid-oxidase by soil humic acids fractionated on sephadex. Soil Biol Biochem 4:469-473

68. Nardi S, Pizzeghello D, Gessa C, Ferrarese L, Trainotti L, Casadoro G (2000) A low molecular weight humic fraction on nitrate uptake and protein synthesis in maize seedlings. Soil Biol Biochem 32:415-419

69. Piccolo A (2001) The supramolecular structure of humic substances. Soil Sci $166: 810-833$

70. Hirel B, Bertin P, Quillere I, Bourdoncle W, Attagnant C, Dellay C, Gouy A, Cadiou C, Retailliau S, Falque M, Gallais A (2001) Towards a better understanding of the genetic and physiological basis for nitrogen use efficiency in maize. Plant Physiol 125:1258-1270

71. Azevedo RA, Lancien M, Lea PJ (2006) The aspartic acid metabolic pathway, an exciting and essential pathway in plants. Amino acids 30:143-162

72. Hirel B, Martin A, Terce-Laforgue T, Gonzalez-Moro MB, Estavillo JM (2005) Physiology of maize I: a comprehensive and integrated view of nitrogen metabolism in a C4 plant. Physiol Plant 124:167-177

73. Lea PJ, Sodek L, Parry MAJ, Shewry PR, Halford NG (2007) Asparagine in plants. Ann Appl Biol 150:1-26

74. Smejkalova D, Piccolo A (2008) Aggregation and disaggregation of humic supramolecular assemblies by NMR diffusion ordered spectroscopy (DOSY-NMR). Envir Sci Technol 42:699-706
75. Azevedo RA, Arruda P, Turner WL, Lea PJ (1997) The biosynthesis and metabolism of the aspartate derived amino acids in higher plants. Phytochem 46:395-419

76. Nikolic M, Cesco S, Römheld V, Varanini Z, Pinton R (2003) Uptake of iron complexed to water-extractable humic substances by sunflower leaves. J Plant Nutr 26:2243-2252

\section{Submit your manuscript to a SpringerOpen ${ }^{\circ}$ journal and benefit from:}

- Convenient online submission

- Rigorous peer review

- Immediate publication on acceptance

- Open access: articles freely available online

- High visibility within the field

- Retaining the copyright to your article

Submit your next manuscript at $>$ springeropen.com 